\title{
ОПЫТ СОЗДАНИЯ И СОДЕРЖАНИЕ ПОЧВЕННО- ЭКОЛОГИЧЕСКОЙ КАРТЫ ЯМАЛО-НЕНЕЦКОГО АВТОНОМНОГО ОКРУГА
}

\author{
(C) 2017 г. И. С. Михайлов, С. И. Михайлов \\ Почвенный институт им. В.В. Докучаева, \\ Россия, 119017, Москва, Пыжевский пер., 7, стр. 2 \\ e-mail: is-mikhaylov@yandex.ru
}

Почвенно-экологическая карта Ямало-Ненецкого автономного округа отображает состояние почвенного покрова территории этого субъекта Российской Федерации. Карта выполнена в системе ГИС с применением дистанционных методов. Новая информация и использование дистанционных методов позволили значительно увеличить количество почвенных контуров, уточнить их границы, выделить участки земель, нарушенных при добыче углеводородного сырья. На карте выделяются почвенные контуры, показывающие доминирующие и сопутствующие почвы и структуру почвенного покрова в виде сочетаний и комплексов почв. В отдельных слоях представлена информация о почвообразующих породах и условиях рельефа выделенных контуров. Самостоятельным слоем показаны почвенно-географические районы, различающиеся строением почвенного покрова. Почвенно-экологическая карта округа отображает подробно особенности почвенного покрова региона. Обозначены более 4000 выделов, показывающих комбинации почв: сочетания, комплексы, гомогенные ареалы. Кроме характеристики почвенного покрова карта содержит 4 слоя информации о выделах: гранулометрический состав, характеристика рельефа, площадь контура, принадлежность к почвенно-географическому району. На территории округа выделено 50 почвенно-географических районов, различающихся особенностями почвенного покрова. Особенное внимание уделено выделам, где почвенный покров нарушен при хозяйственной деятельности человека. Кроме ареалов распространения почв на карте выделяются отдельными контурами нарушенные земли городов и районов добычи нефти и газа. Карта показывает распределение почвенного покрова и характер поверхностных отложений. Она отвечает на вопросы, возникающие при его изучении, охраны окружающей природной среды и хозяйственного освоения земель, включая прокладку объектов инфрастуктуры и проблемы отгонного оленеводства.

Ключевые слова: почвенно-экологическая карта, почвенный покров, Арктика, Ямало-Ненецкий автономный округ.

DOI: 10.19047/0136-1694-2017-87-55-72 
Бюллетень Почвенного института им. В.В. Докучаева. 2017. Вып. 87.

\section{ВВЕДЕНИЕ}

Ямало-Ненецкий автономный округ - один из быстро развивающихся субъектов Российской Федерации. Он расположен в суровых условиях Арктики и Субарктики. Его площадь составляет

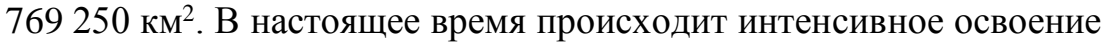
природных ресурсов региона. Поэтому необходимо изучение и отображение экологических особенностей его территории, в том числе и почвенных ресурсов.

Впервые на территории округа почвы Гыданского полуострова изучались Б.Н. Городковым (1932). На полуострове Ямал детальные исследования почв проводились В.Д Васильевской и др. (1986). Почвы таежной зоны Западной Сибири изучались Н.А. Караваевой (1973), И.П. Гавриловой и Л.С. Долговой (1972), И.М. Гаджиевым и С.Т. Овчинниковым (1978). Основная часть этих исследований проводилась на смежной территории ХантыМансийского округа. Наибольший вклад в исследования почв тундровой и таежной зоны Ямал-Ненецкого округа внесли В.Д Тонконогов $(\underline{1977}, \underline{2010})$ и О.А. Дворников (Тонконогов, Дворников, 1988; Дворников, 2000).

Почвенный покров Ямало-Ненецкого округа отображен на почвенной карте РСФСР масштаба 1: 2500000 (1988). В Почвенном институте им. В.В. Докучаева на территорию автономного округа в конце прошлого века составлены листы Государственной почвенной карты масштаба $1: 1000$ 000. Авторы: В.Д Тонконогов, О.А. Дворников, Р.П. Михайлова, Н.Я. Мясникова. Эти карты, а также опубликованные материалы использованы при составлении почвенно-экологической карты Ямало-Ненцкого автономного округа.

\section{МЕТОДЫ КАРТОГРАФРОВАНИЯ}

Экологические условия Ямало-Ненецкого автономного округа разнообразны. В него входят тундра, лесотундра, северная и средняя тайга. Большую часть территории округа занимает Западно-Сибирская равнина. Вдоль западной границы протянулся Полярный Урал с его отрогами. На востоке расположены Сибирские Увалы, среди которых выделяется Верхнетазовская возвышенность. 
Бюллетень Почвенного института им. В.В. Докучаева. 2017. Вып. 87.

В 2015-2016 гг. в отделе Генезиса и географии почв Почвенного института им. В.В. Докучаева разработана Почвенноэкологическая карта Ямало-Ненецкого автономного округа. Карта охватывает территорию округа, включая острова Карского моря, полуострова: Ямал, Тазовский, Гыданский, Явай и состоит из 16 листов международной карты масштаба 1 : 1000000.

Карта составлена в компьютерном варианте с использованием GIS-технологий на основе топографических карт масштаба 1 : : 500000 и скорректирована по снимкам Landsat. Оптимальный масштаб для использования карты $1: 500000$.

При составлении карты использовались листы Государственной почвенной карты. Широко применяли информацию с мелкомасштабных тематических карт: геологических, геоморфологических, геоботанических, геокриологических и других, а также опубликованные и фондовые материалы.

На карте округа основными картографическими единицами являются почвенные выделы, отображающие особенности почвенного покрова. Они несут информацию о почвах, входящих в данный выдел, и характере структуры почвенного покрова.

Кроме характеристик почвенного покрова, в виде отдельных слоев информационных таблицах приведены сведения о характере почвообразующих пород и рельефа, почвенно-географических районах, площадях контуров. В качестве экологических показателей отображались антропогенные нарушения почвенного покрова.

\section{РЕЗУЛЬТАТЫ И ОБСУЖДЕНИЕ}

В результате проделанной работы составлена почвенная карта Ямало-Ненецкого автономного округа. Карта содержит 4054 почвенных контура. Всего на карте различаются 65 типов выделов, отображающих почвенные комбинации (сочетания, комплексы). Три типа выделов показывают нарушенные земли в результате индустриального освоения территории.

Ниже приводится краткая характеристика почв, входящих в комбинации. На островах Карского моря, за исключением прибрежной части, распространены полигональные арктические почвы (пелоземы языковатые).

В арктической тундре на суглинистых щебнистосуглинистых грунтах в наиболее дренированных участках распро- 
Бюллетень Почвенного института им. В.В. Докучаева. 2017. Вып. 87.

странены гумусированные слабоглеевые (глееватые) почвы с профилем $\mathrm{AO}-\mathrm{A}-\mathrm{CRMg}-\mathrm{C}(\mathrm{D})^{l}$. Наименование почв предложено В.Д. Васильевской (1988). Вероятно, они близки к грубогумусовым криометаморфическим глееватым почвам в классификации почв России (2004). Они имеют полигональное строение. Бордюры мохово-кустарничковой растительности, расположенные над трещинами, окаймляют полигоны диаметром 30-40 см, лишенные растительности. Под растительностью по трещинам формируются клиновидные гор. О, АК. Над поверхностью многолетней мерзлоты может наблюдаться слабо выраженный глееватый горизонт. Эти почвы могут входить в сочетания с подбурами и глееземами торфянистыми.

Широко распространены на территории тундры, лесотундры и северной тайги особенно на песчаных грунтах почвы пятен пелоземы с профилем $\mathrm{W}-\mathrm{C}$. Они являются компонентом комплексов с широким спектром почв: подбурами, глееземами. Поверхность их лишена растительности, за исключением корочки синезеленых водорослей или редких лишайников. Почвенный профиль слабо развит, иногда могут проявляться признаки криотурбаций.

Подзолистые торфянисто-глееватые почвы $(\mathrm{O}-\mathrm{El}-\mathrm{BEl}(\mathrm{g})-$ $\mathrm{BTg}-\mathrm{Cg}$ ) встречаются на слабодренированных речных террасах, сложенных песками и супесями, переслаивающимися с суглинками. Особенности их генезиса В.Д. Тонконогов (2010) связывал с неоднородностью материнских пород.

Подзолисто-глеевые почвы (O-El-BElg-BTg-G-CG) широко распространены на территории таежной зоны округа, особенно в его южной части. Они занимают слабодренированные местообитания по периферии болот на песчаных и супесчаных породах под редкостойными хвойными лесами с кустарничковым подлеском. Эти почвы могут образовывать сочетания с глееземами торфяными и светлоземами глееватыми.

Подбуры грубогумусированные (Оао-ВНF-С) встречаются в таежной зоне на хорошо дренированных песках и на щебнистых грунтах в предгорьях Урала. Они образуют сочетания и мозаики с

${ }^{1}$ Индексация горизонтов почвенных профилей проводится согласно Классификации и диагностике почв России (2004). 
Бюллетень Почвенного института им. В.В. Докучаева. 2017. Вып. 87.

подзолами иллювиально-железистыми, примитивными щебнистыми почвами (петроземами) и подзолисто-глеевыми почвами.

Подбуры перегнойные (Oh-BHF-C) широко распространены на территории тундры, лесотундры и северной тайги на песчаных террасах под мохово-лишайниковыми тундрами и редколесьями. Они образуют сочетания с глееземами торфянистыми и торфянисто-перегнойными и комплексы с подзолистыми глеевыми почвами.

Подбуры иллювиально-железистые (O-BF-C) образуют сочетания с подзолами иллювиально-железистыми и иллювиальногумусовыми. Они распространены в предгорьях Полярного Урала на склонах пологих увалов на щебнисто-мелкоземных делювиальных отложениях под лиственничными редколесьями.

Подбуры иллювиально-гумусовые (O-BH-(BF)-C) встречаются на террасах нижнего течения р. Обь на песках под разреженной тайгой с кустарничковым подлеском. Эти почвы могут образовывать комплексы с подзолами иллювиально-гумусовыми.

Подбуры поверхностно-глеевые $(\mathrm{O}-\mathrm{BHg}-\mathrm{D})$ встречаются на моренных грядах Предуралья на двучленных отложениях - песках и супесях, подстилаемых суглинками и глинами под лиственничными редколесьями.

Подбуры (без разделения) выделены в тундровой зоне на легких породах под мохово-лишайниковой растительностью. Профиль этих почв O-BH-BF-C. Они могут входить в сочетания с глееземами торфянистыми и грубогумусными, а также с развеваемыми песками (псаммоземами).

Подзоль иллювиально-гумусовые (О-Е-ВН-(BF)-C) широко распространены на песчаных отложениях в южной части территории округа под разреженной светлохвойной тайгой, где могут образовывать сочетания с псаммоземами и глееземами торфяными и входить в комплексы с подзолами иллювиально-железистыми. Они также встречаются в предгорьях Урала, где могут образовывать сочетания с примитивными щебнистыми почвами (литоземами).

Подзольь иллювиально-железистые (O-E-BF-C) доминируют на легких породах в средней части округа (северной тайге, лесотундре), включая возвышенности Приуралья и Сибирских увалов, под светлохвойным редколесьем. Эти почвы образуют комплексы с подзолами иллювиально-гумусовыми, сочетания с боло- 
Бюллетень Почвенного института им. В.В. Докучаева. 2017. Вып. 87.

тами и песками. В Приуральской части они могут образовывать сочетания с подбурами и примитивными щебнистыми почвами. На Сибирских увалах - со светлоземами глееватыми.

Подзолы глеевые (O-Eg-BHFg-G-CG) распространены на плохо дренированных участках в южной тундре и редкостойной северной тайге с кустарничково-моховым напочвенным покровом на песках и супесях. Они образуют комплексы с подбурами перегнойными и могут входить в сочетания с глееземами торфянистыми и торфяными, а также с олиготрофными торфяниками.

Криоземы торфянисто-перегнойные (Oh-CR-C) встречаются только на Полярном Урале по днищам широких ледниковых долин с разреженной тундровой растительностью. Они образуют сочетания с подбурами грубогумусными и примитивными щебнистыми почвами (литоземами).

Светлоземь типичные (O-E-CRM-C) распространены на хорошо дренированных суглинках в южной тайге под моховокустарничковыми елово-пихтовыми лесами, преимущественно в восточной части Сибирских увалов.

Светлоземы глееватые $(\mathrm{O}-\mathrm{E}(\mathrm{g})-\mathrm{CRMg}-\mathrm{Cg})$ распространены в тех же условиях, что и предыдущие почвы, но на менее дренированных местообитаниях под пихтовыми лесами моховокустарничковым покровом. Основная части их ареала приурочена к Верхнетазовской возвышенности. Они могут образовывать сочетания с подзолистыми глеевыми почвами.

Глееземы поверхностно-глеевые $(\mathrm{O}-\mathrm{G}-\mathrm{D})$ распространены в предгорьях Урала под кустарничково-моховой тундрой на двучленных породах, где пески и супеси подстилаются суглинками на глубине менее метра. Они могут образовывать комплексы с почвами пятен, глееземами торфянистыми и торфянистоперегнойными.

Глееземы грубогумусированные (Оао-G-CG) занимают в тундровой зоне повышенные, дренированные участки под кустарничковой мохово-злаковой тундрой. Они образуют комплексы с глееземами торфянистыми и почвами пятен и могут входить в сочетания с комплексами глееземов торфянисто-перегнойных и торфяных.

Глееземы торфянистые $(\mathrm{O}-\mathrm{G}-\mathrm{CG})$ широко распространены в тундровой зоне округа, особенно в северной ее части на равни- 
Бюллетень Почвенного института им. В.В. Докучаева. 2017. Вып. 87.

нах. Они образуют комплексы с глееземами торфянистоперегнойными и сочетания с подбурами, слабоглевыми гумусированными почвами, глееземами торфяными.

Глееземы торфянисто-перегнойные (Oh-G-CG) широко распространены на Западно-Сибирской равнине в подзоне южной тундры, лесотундре. Могут заходить в среднюю тайгу. Они образуют комплексы с глееземами торфянистыми или торфяными. Эти комплексы могут входить в сочетания с подбурами, подзолистыми глеевыми почвами, глееземами оподзоленными и торфяными.

Глееземы оподзоленные $(\mathrm{O}-\mathrm{Ge}-\mathrm{G}-\mathrm{CG})$ встречаются на равнине в зоне тайги под светлохвойными лесами. Они образуют сочетания с глееземами торфянисто-перегнойными.

Глееземы торфяные (торфяно-глееземы) имеют профиль ТG-CG. Это плоскобугристые болота (Лисс, Березина, 1981). Они широко распространены на всей территории округа, за исключением самых северных районов. Имеют мощность торфяного горизонта до 1 м. Эти почвы также встречаются в долинах равнинных рек. Они входят в комплексы с глееземами торфянистыми, торфянисто-перегнойными и торфяниками олиготрофными. Эти комплексы сочетаются с подбурами, подзолистыми глеевыми почвами, маршевыми засоленными почвами.

Торфянистые почвы на ледяных жилах (O-D лед) формируются на крайнем севере округа в термокарстовых западинах и поймах рек. Маломощный торфянистый горизонт залегает на поверхности ледяных жил. Такие почвы являются компонентом тетрагональных болот, располагаясь на валиках над ледяными жилами. Пространство между валиками занято комплексом глееземов торфянисто-перегнойных и торфяных.

Торфяники олиготрофныье (ТО-ТТ) широко распространены на Западно-Сибирской равнине, за исключением арктической тундры (Топологическая карта болот Западно-Сибирской равнины, 1975). Они покрыты с поверхности очесом мхов преимущественно сфагновых. Ниже располагаются горизонты мхов в различной степени разложения. Мощность торфа может достигать 46 м (исс, Березина, 1981). Торфяники олиготофные могут образовывать комплексы с глееземами торфяными. Эти комплексы в свою очередь могут образовывать самостоятельные контуры или 
Бюллетень Почвенного института им. В.В. Докучаева. 2017. Вып. 87.

входить в сочетания с подзолисто-глеевыми почвами, подзолами иллювиально-железистыми, подбурами перегнойными.

Примитивные щебнистые почвы (петроземы) имеют профиль (О-М). В пределах округа встречаются на Полярном Урале и его предгорьях. На вершинных плато и крутых склонах они могут чередоваться с каменными россыпями и выходами коренных пород. На более пологих склонах они образуют сочетания с подбурами, криоземами и подзолами илллювиальногумусовыми.

Пески (Псаммоземы) (W-C). Слабо закрепленные растительностью пески широко распространены на поймах и террасах рек Западной Сибири. На отдельных участках могут образовываться речные дюны. Псаммоземы могут образовывать сочетания в тундровой зоне с подбурами, в таежной зоне - с подзолами иллювиально-гумусовыми

Маршевые засоленные почвы (W-SS) занимают низменные побережья Карского моря, а также встречаются в дельтах рек. Тыльная сторона ареала этих почв покрыта солевыносливыми растениями. Ближе к морю идет обширная полоса черного ила с запахом сероводорода. В дельтах рек эти почвы могут входить в сочетания с аллювиальными почвами, на низменных побережьях - с глееземами торфяными.

Аллювиальные слаборазвитье почвы (W-C ) распространены в поймах рек. На равнине они преимущественно песчаные, в горных и предгорных районах - галечниковые. Они могут образовывать комплексы с аллювиальными торфяными почвами, в дельтах рек - с маршевыми засоленными почвами.

Аллювиальные торфяные почвы (Т-CG ) преобладают в поймах рек Западно-Сибирской равнины и образуют комплексы с аллювиальными слаборазвитыми почвами и глееземами торфяными.

Кроме ареалов вышеперечисленных почв, на карте выделяются отдельными контурами три категории земель:

- нарушенные земли городов и промышленных предприятий,

- нарушенные земли нефте-газопромыслов,

- частично нарушенные земли нефте-газопромыслов.

Для характеристики почвенного покрова принята цифровая индексация контуров (картографических единиц) Индексация контуров карты Ямало-Ненецкого округа соответствует таковой 
Бюллетень Почвенного института им. В.В. Докучаева. 2017. Вып. 87.

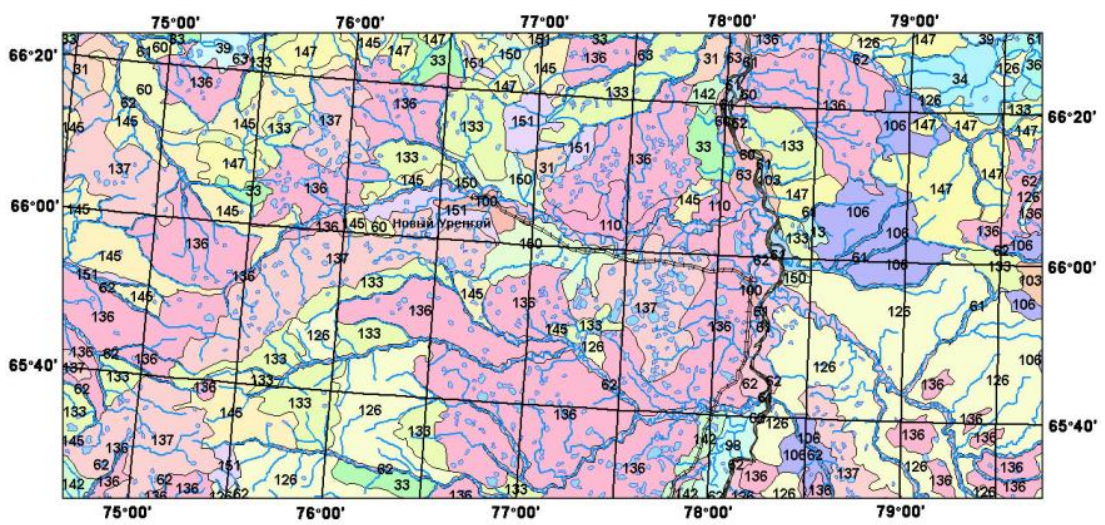

Рис. 1. Фрагмент листа Q 43-44 Новый Уренгой. Масштаб 1: 1000000. 33 - комплекс глееземов торфянисто-перегнойных и глееземов торфянистых в сочетании с подбурами грубогумусированными, 34 - комплекс глееземов торфянисто-перегнойных и глееземов торфянистых в сочетании с глееземами грубогумусными, 60 - пески, 61 - аллювиальный комплекс, 62 - аллювиальный болотный комплекс, 100 - нарушенные земли городов, 103 - комплекс подзолов иллювиально-гумусовых и подзолов иллювиально-железистых, 106 - сочетание подзолов иллювиальногумусовых с комплексом торфяно-глееземов и торфяных олиготрофных, 110 - сочетание подзолов иллювиально-железистых с комплексом торфяно-глееземов и торфяных олиготрофных, 126 - сочетание подзолистоглеевых почв с подзолами иллювиально-железистыми, 133 - комплекс глееземов торфяных и торфяников олиготрофных, 137 - торфяники олиготрофные. 145 - светлоземы глееватые, 147 - сочетание глееземов оподзоленных и глееземов торфянисто-перегнойных, 150 - нарушенные земли нефте-газопромыслов, 151 - частично нарушенные земли нефтегазопромыслов.

для Почвенной карты Российской Арктики (Михайлов, 2016). В качестве примера приведем фрагмент карты на район Нового Уренгоя (рис. 1).

Информация о почвообразующих породах приведена в виде атрибута в базе данных ГИС. Принципы выделения почвообразующих пород соответствуют таковым на Государственной почвенной карте, но их список расширен. Почвообразующие породы включают: рыхлые отложения: пески и супеси, легкие и средние суглинки, тяжелые суглинки и глины, двучленные отложения 
Бюллетень Почвенного института им. В.В. Докучаева. 2017. Вып. 87.

(пески и супеси на суглинках и глинах), суглинки с участием жильных льдов.

В долинах и дельтах рек выделяются аллювиальные отложения смешанного состава (пески, суглинки), аллювиальные отложения со слоями торфа. Отдельно рассматривается торф как почвообразующая порода.

На Полярном Урале почвообразование осуществляется на щебнистом элювии и делювии. Здесь преобладают кислые изверженные породы, преимущественно граниты. Локально встречаются основные изверженные породы. В предгорьях Урала на возвышенностях на поверхность выходят плотные осадочные породы (песчаники, сланцы). На шлейфах гор встречаются рыхлые породы с включением обломков твердых пород.

Для характеристики почвообразующих пород разработана система цифровой индексации выделов. Всего использовано 14 цифровых индексов.

Основную часть территории Ямало-Ненецкого округа занимает Западно-Сибирская равнина. Только по западной границе проходит горный хребет Полярный Урал с примыкающими предгорными возвышенностями. На юго-востоке округа располагаются возвышенности: Сибирские увалы и Верхнетазовская, достигающие высот до 250 м. На карте округа выделено 5 типов рельефа: низменности, возвышенности, горы, речные долины и дельты рек.

В границах Ямало-Ненецкого округа выделяются 50 почвенно-географических районов. Они входят в различные почвенные зоны и различаются особенностями почвенного покрова (характером почвообразующих пород, степенью заболоченности).

Арктическая зона представлена районом 2 - острова южной части Карского моря. В него входят острова Арктического института, Известий ЦИК и остров Свердрупа. Острова низменны, сложены морскими отложениями легкого гранулометрического состава. Большие площади заняты песками и отмелями, заливаемыми во время приливов. Растительность - арктическая моховолишайниковая тундра. На островах преобладает комплекс арктических и арктических гидроморфных почв и песков.

Арктотундровая зона в нее входят районы, располагающиеся вдоль побережья Карского моря и на прибрежных островах. В зависимости от литологических особенностей выделяются три 
Бюллетень Почвенного института им. В.В. Докучаева. 2017. Вып. 87.

группы районов. К первой группе относятся районы, сложенные преимущественно песками. В них преобладают подбуры песчаные, занимающие до 40\% территории, в сочетании с глееземами торфянистыми и торфянисто-перегнойными (25\%). К этому типу районов относятся районы 5 - Харасовейский и 7 - Южный Явайский.

Во вторую группу входит районы, где преобладают глееземы торфянстые и торфянисто-перегнойные (45\%), но наблюдается значительное участие подбуров песчаных (20\%). К ним относятся районы 4 - острова Шокальского и северной части полуострова Явай и 10 - Байдараикий.

К третьей группе относятся районы, где преобладают суглинки с включением ископаемых льдов. В них доминируют глееземы торфянисто-перегнойные (40\%). Значительные площади занимают глееземы торфяные (20\%). На дренированных участках развиваются слабоглеевые гумусированные почвы (5\%). К этой группе относятся районы: 1 - острова Белого, 3 - островов Сибирякова и Олений, 6-Тамбейский, 8 -Северный Гыданский и 12 Каменномысский.

Тундровая зона располагается обширной полосой в южной части полуостровов Ямал, Гыдан и Тазовского, а также в междуречье низовий рек Оби, Пура и Таза. В этой зоне также выделяется несколько групп районов.

В первую группу входит один район 18 - Западный Гыданский. В нем преобладают легкие почвообразующие породы. В почвенном покрове преобладают подбуры перегнойные (50\%). Значительные площади занимают глееземы торфянистоперегнойные (20\%). Встречаются пески.

Ко второй группе относятся районы, в которых преобладают суглинистые почвообразующие породы, но значительны площади песков и супесей. В почвенном покрове доминируют глееземы торфянисто-перегнойные (50\%). Широко распространены глееземы торфяные $(10 \%)$ и подбуры перегнойные (10\%). В эту группу входят районы: 11 - Маре-Сальский, 15 - Мессояхский, 17-Танамский, 40 - Табъяхский.

В третью группу районов входят территории, сложенные древнеаллювиальными отложениями преимущественно суглинистого состава со значительными включениями ископаемого льда. 
Бюллетень Почвенного института им. В.В. Докучаева. 2017. Вып. 87.

Широко развит термокарст. В почвенном покрове преобладают глееземы торфянисто-перегнойные. (45\%). Значительные площади занимают глееземы торфяные (20\%) На наиболее дренированных участках могут развиваться глееземы грубогумусные (6\%). К этой группе относятся районы: 13 - Тазовского полуострова, 14 - Центральный Гыданский, 16 - Верхненереяхский.

Лесотундровая зона, где древесная растительность вторгается в тундру по наиболее благоприятным местообитаниям, протягивается узкой полосой вдоль Урала в междуречьях низовий Оби Пура и Таза. В ней выделяются группы районов, различающихся по экологическим условиям и характеру почвенного покрова.

В лесотундре выделяется район 19 - Приуральский с грядово-холмистым рельефом. Гряды сложены щебнистыми породами и ледниковыми моренами и разделены широкими межгорными долинами. Леса занимают склоны холмов южной и западной экспозиции. Остальные местообитания занимают тундры. В почвенном покрове преобладают глееземы торфянисто-перегнойные, развивающиеся в межгрядовых понижениях (30\%). На вершинах и склонах гряд развиваются подбуры перегнойные (25\%). Также широко распространены поверхностно-глеевые почвы (20\%).

В эту же зону входит район 24 - Салехардский, представляющий равнину с преобладанием пород легкого гранулометрического состава. Лесная растительность развивается по берегам рек. В почвенном покрове преобладают подбуры перегнойные (50\%). Значительную площадь занимают болота с глееземами торфяными и торфяниками олиготрофными. (20\%) Там, где преобладают суглинки, распространены светлоземы глееватые (20\%).

Расположенный ближе к Уралу район 20 - Лабытнангский более залесен. Большие площади занимают суглинистые породы. На них на хорошо дренированных участках развиваются светлоземы глееватые (10\%). На менее дренированных - подзолистоглеевые почвы (30\%). На песках и супесях преобладают подбуры перегнойные (20\%). Значительна заболоченность района: глееземы торфяные и торфяники олиготрофные (20\%)

Большую площадь лесотундровой зоны составляют сильно заболоченные районы. Комплексы торфяников олиготрофных и глееземов торфяных занимают 50-60\% площади. Вокруг болот распространены подзолисто-глеевые почвы (15-20\%) и глееземы 
Бюллетень Почвенного института им. В.В. Докучаева. 2017. Вып. 87.

торфянисто-перегнойные (10-15\%). К этой группе относятся районы: 33 - Новоуренгойский, 45 - Тютнюяхский, 47 - Красноселькупский.

В лесотундровой зоне выделяется район 37 - Самбургский. Он расположен в узком междуречье Пура и Таза на террасах этих рек с легкими почвообразующими породами под светлохвойной лесотундрой. 50\% территории района занимают глееземы оподзоленные, $20 \%$ - глееземы торфяные и 15\% - глееземы торфянистоперегнойные.

Северо-таежная подзона занимает центральную часть округа. Это плоская аллювиальная равнина, прерываемая возвышенностями Сибирских увалов, с редкостойной заболоченной темнохвойной тайгой. Эта подзона включает четыре группы районов, различающихся по характеру почвенного покрова.

В первой группе относятся районе с доминированием подзолисто-глеевых почв, занимающих 50\% территории. Значительные площади занимают болотные комплексы глееземов торфяных и торфяников олиготрофных (30\%). На наиболее дренированных участках развиваются подзолы иллювиально-железистые. К этой группе относятся районы: 21 -Обь-Сонинский, 26 - Куноватский, 30 - Лонгъяхский, 43 - Тольский, 44 - Староуренгойский.

Во вторую группу входят районы, где почвенный покров более разнообразен и почвы распределены более равномерно. Подзолисто-глеевые почвы занимают 20\% территории района. Подбуры, развивающиеся на песках и супесях, также 20\%. Светлоземы - на наиболее дренированных участках $-20 \%$ и болотный комплекс глееземов торфяных и торфяников олиготрофных $-20 \%$. К этому типу районов относятся районы 25 - Полуйский и $46-$ Сидоровский.

К третьей группе относятся районы, расположенные на хорошо дренированных возвышенностях с суглинистыми покровными отложениями под пихтово-кедровыми сомкнутыми лесами. В почвенном покрове доминируют светлоземы (50\%). На песчаных речных террасах развиваются подзолы иллювиальножелезистые и иллювиально-гумусовые (20\%). В наименее дренированных местах подзолисто-глеевые почвы (15\%). К этой группе относятся районы: 27 - Верхнекуноватский и 39 - Верхнетазовский. 
Бюллетень Почвенного института им. В.В. Докучаева. 2017. Вып. 87.

В четвертую группу входят низменные заболоченные районы. Большую часть их площади (60-70\%) занимает болотный комплекс торфяников олиготрофных и глееземов торфяных. На прилегающих к болотам участках, сложенных суглинками, развиваются подзолисто-глеевые почвы (15-20\%). На песках - подзолы иллювиально-железистые (10-15\%). Возвышенные и хорошо дренированные участки занимают светлоземы (до 10\%). В эту группу входят районы: 28 - Нижнеполуйский, 31 - Хетский, 32 - Верхненадымский, 41 - Среднепурский, 48 - Пекмыльский.

Среднетаежная подзона занимает крайнюю южную часть округа. Она представляет собой низменную заболоченную аллювиальную равнину, за исключением отрогов Сибирских увалов. Лесная растительность более сомкнута, чем в подзоне северной тайги. На песках и супесях преобладает светлохвойная тайга, на суглинках - темнохвойные леса. В этой подзоне выделяются почвенно-географические районы, различающиеся по характеру и строению почвенного покрова.

Среди них выделяется район 50 - Раттский, расположенный на Верхнетазовской возвышенности на суглинистых покровных отложениях под пихтово-кедровой тайгой. Основной фон составляют светлоземы глееватые (70\%) На суглинках развиваются подзолисто-глеевые почвы (10\%), на песках - подзолы иллювиально-железистые (10\%).

Большую площадь на юге округа занимает район $49-\mathrm{Ho}$ ябрьский. Это плоская равнина, расчлененная реками. С кедровопихтовой тайгой и лиственными лесами. В почвенном покрове доминируют подзолисто-глеевые почвы (50\%). Болотный комплекс торфяников олиготрофных и глееземов торфяных занимает $30 \%$ площади. Подзолы иллювиально-железистые (10\%) развиваются по террасам рек.

Третью группу районов этой подзоны представляют низменные сильнозаболоченные районы; 60-70\% их территории занимают болотные комплексы: торфяники олиготрофные и глееземы торфяные. Меньшую площадь занимают подзолисто-глеевые почвы (20-30\%) и подзолы иллювиально-железистые и иллювиально-гумусные (10-15\%). К этой группе относятся районы: 34 Пурпейский, 35 - Пягопурский, 42 - Айваседопурский. 
Бюллетень Почвенного института им. В.В. Докучаева. 2017. Вып. 87.
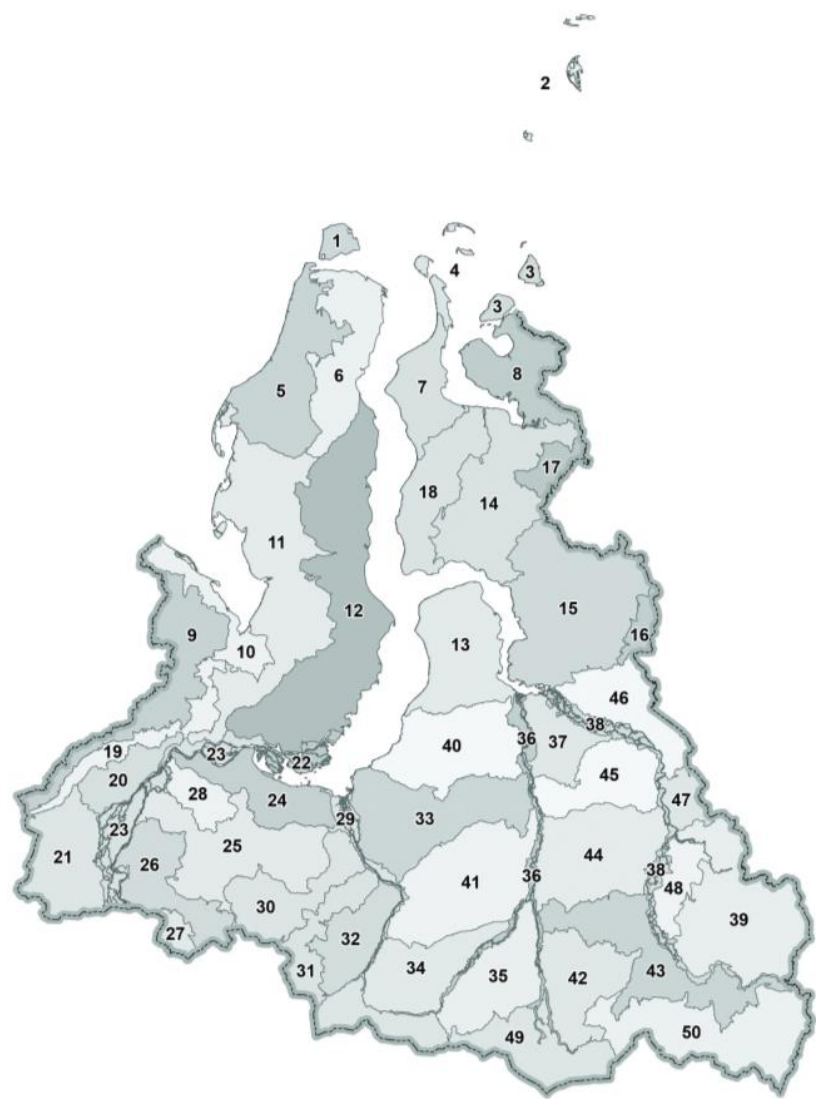

Рис. 2. Картосхема почвенно-географического районирования Ямало-Ненецкого округа: 1 - остров Белый, 2 - острова южной части Карского моря, 3 - острова Сибирякова и Олений, 4 - остров Шокальского и северная часть полуострова Явай, 5 - Харасовейский, 6 - Тамбейский, 7 - Южный Явайский, 8 - Северный Гыданский, 9 - Полярного Урала, 10 - Байдарацкий, 11 - Маре-Сальский, 12 Каменномыский, 13 - Тазовский полуостров, 14 - Центральный Гыданский, 15 Мессояхский, 16 - Верхненереяхский, 17 - Танамский, 18 - Западный Гыданский, 19 -Приуральский, 20 - Лабытнангский, 21 - Обско-Сонинской, 22 - устье p. Обь, 23 - долина р. Обь, 24 - Салехардский, 25 - Полуйский, 26 - Куноватский, 27 - Верхнекуноватский, 28 - Нижнеполуйский, 29 - долина р. Надым, 30 Лонгъяхский, 31 - Хетский, 32 - Верхненадымский, 33 - Новоуренгойский, 34 Пурпейский, 35 - Пягопурский, 36 - долина р. Пур, 37 - Самбургский, 38 - долина р. Таз, 39 - Верхнетазовский, 40 - Табъяхский, 41 - Среднепурский, 42 Айваседопурский, 43 - Тольский, 44 - Староуренгойский, 45 - Тютнюяхский, 46 - Сидоровский, 47 - Красноселькупский, 48 - Пекмыльский, 49 - Ноябрьский, 50 - Раттский. 
Бюллетень Почвенного института им. В.В. Докучаева. 2017. Вып. 87.

частях рек могут встречаться маршевые засоленные почвы. В эту группу входят районы: 22 - дельты р. Обь, 23 - долины На западной границе округа расположен горный почвенно-географический район 9 - Уральский. Горы сложены кислыми изверженными и метаморфическими породами. Растительность горные тундры. В почвенном покрове преобладают каменные россыпи и примитивные щебнистые почвы, занимающие 55\% территории района. На склонах гор развиваются подбуры грубогумусные (20\%). По днищам ледниковых долин (трогов) развиваются криоземы торфянисто-перегнойные $(10 \%)$, которые чередуются и глееземами торфянистыми (10\%).

Отдельную интразональную группу районов составляют долины больших рек округа. В этих районах преобладают аллювиальные торфяные и аллювиальные примитивные почвы. В устьевых p. Обь, 29-долинь р. Надылм, 36 - долины р. Пур. 38 - долины р. Таз. Картосхема почвенно-географических районов приводится на рис. 2.

\section{ЗАКЛЮЧЕНИЕ}

Почвенная карта Ямало-Ненецкого автономного округа впервые составлена в унифицированной легенде для всех листов с применением новой классификации почв России (2004). Преимуществом этой карты является ее создание в формате ГИС, что позволяет проводить ее постоянное обновление по мере поступления новой информации. При использовании интернета она может быть доступной широкому кругу пользователей. Карта может быть использована при освоении этого региона, проектирования объектов инфраструктуры, планировании развития отгонного оленеводства и мероприятий по охране окружающей среды.

\section{СПИСОК ЛИТЕРАТУРЫ}

1. Васильевская В.Д., Иванов В.В., Богатырев Л.Г. Почвы севера Западной Сибири. М.: Изд-во Моск. ун-та, 1988. 227 с.

2. Гаврилова И.П., Долгова Л.С. Песчаные почвы среднетаежной подзоны Западной Сибири // Природные условия Западной Сибири. М.: Изд-во Моск. ун-та, 1972. Вып. 2. С. 34-50.

3. Гаджиев И.М., Овчинников С.М. Почвы средней тайги Западной Сибири. Новосибирск: Наука. Сиб. отд., 1978. 152 с. 
Бюллетень Почвенного института им. В.В. Докучаева. 2017. Вып. 87.

4. Городков Б.Н. Почвы Гыданской тундры // Тр. Полярной комиссии АН СССР. 1932. Вып. 7. С. 19-22.

5. Дворников О.А. Почвенный покров центральной части Гыданского полуострова. Генезис, география и картография почв: Научн. тр. Почв. ин-та. М., 2000. С. 291-302.

6. Караваева Н.А. Почвы тайги Западной Сибири. М.: Наука, $1973.167 \mathrm{c}$.

7. Классификация и диагностика почв России. Смоленск: Ойкумена, 2004. $342 \mathrm{c}$.

8. Лисс О.Л. Березина Н.А. Болота Западной Сибири. М.: Изд-во Моск. ун-та, 1981. 206 с.

9. Михайлов И.С. Почвенная карта Российской Арктики масштаба $1: 000$ 000. Содержание и опыт составления // Почвоведение. 2016. № 4. C. 411-419. doi: 10.7868/S0032180X16040092

10.Почвенная карта РСФСР. Масштаб 1: 2500000 / Под ред. Фридланда В.М. М.: ГУГК, 1988.

11.Типологическая карта болот Западно-Сибирской равнины. М.: ГУГК, 1977.

12.Тонконогов В.Д. Почвенный покров // Ямало-Гыданская область (физико-географическая характеристика). Л.: Гидрометеоиздат, 1977. C. $169-197$.

13.Тонконогов В.Д. Автоморфное почвообразование в тундровой и таежной зонах Восточно-Европейской и Западно-Сибирской равнин. М.: Почв. ин-т им. В.В. Докучаева, 2010. 304 с.

14.Тонконогов В.Д., Дворников О.А. К систематике железистодифференцированных почв холодных и умеренных гумидных областей // Генезис, антропогенная эволюция и рациональное использование почв. Тр. Почв. ин-та им. В.В. Докучаева. М., 1989. С. $122-129$.

\section{THE EXPIRIENCE OF CREATION OF SOIL- ECOLOGICAL MAP OF YAMAL-NENETS AUTONOMOUS DISTRICT}

\section{S. Mikhailov, S. I. Mikhailov}

V.V. Dokuchaev Soil Science Institute, Pyzhevskii per., 7, Moscow, 119017 Russia 
The soil ecologic map of Yamal-Nenets autonomic district reflects the state of the soil cover of the territory of this subject of Russian Federation. The map is created with application of GIS technologies and remote sensing methods. The new information and application of the remote sensing methods allowed us to increase significantly the number of soil contours, verify their borders, manifest the areas of lands, which were disturbed during the hydrocarbon crude mining. We marked the soil contours on the map. These contours show the dominating and accompanying soil types, the structure of the soil cover as soil sequences and complexes. Some layers present the information about the parent rocks and topography conditions for the marked contours. As a separate layer we showed the soil geographic regions, which differ in the composition of the soil cover. The specificities of the regional soil cover is accurately reflected on the soil-ecological map of the district. More than 4000 separations are marked, which show the combinations of soils: sequences, complexes, homogenous areas. The map contains the 4 layers of information about the separations besides the characteristics of the soil cover: texture, topography characteristics, contour area, the relation to soil-geographic region. The territory is divided on 50 soil-geographic regions, which differ by the specificities of the soil cover. The most attention was paid to the lands, which were disturbed by the human activity. Along with the areas of the soil distribution, the separate contours mark the land areas of towns, and those which were disturbed by the mining of oil and gas. The map shows the distribution of the soil cover, and the character of the surface deposits. It answers the questions occurring during its study, environmental protection and agricultural lands cultivation, including the distribution of infrastructure objects and the problems of distantpasture deer farming.

Keywords: soil-ecological map, soil cover, Arctic, Yamal-Nenets autonomous district.

Ссылки для цитирования: Михайлов И.С., Михайлов С.И. Опыт создания и содержание почвенно-экологической карты Ямало-Ненецкого автономного округа // Бюл. Почв. ин-та им. В.В. Докучаева. 2017. Вып. 87. C. 55-72. doi: 10.19047/0136-1694-2017-87-55-72

I.S. Mikhailov, S.I. Mikhailov The Expirience of Creation of Soil-Ecological Map of Yamal-Nenets Autonomous District, Byulleten Pochvennogo instituta im. V.V. Dokuchaeva, 2017, Vol. 87, pp. 55-72. doi: 10.19047/0136-16942017-87-55-72 